\title{
Mapping Advocacy and Outreach for the Scholarship of Teaching and Learning
}

\section{ABSTRACT}

From early days, SoTL scholars have documented the "small significant networks" (Roxå and Mårtensson's term) in which colleagues discuss teaching in local gatherings, as well as in broadly attended conferences and publications. Recent ISSOTL discussions recognize the significance of efforts at this scale and seek to situate them in a larger SoTL landscape, or SoTLscape, of advocacy and outreach activities in the field. In this essay, we present a matrix of possible audiences as an aid to seeing where scholars of teaching and learning are more-and less-active as advocates for SoTL and for positions on pedagogy, curricula, and student success supported by SoTL research. Beyond mapping current activity and looking for gaps, we suggest that the matrix could also help organize pithy accounts of practice into a resource that would stimulate imagination about how scholars of teaching and learning could be more effective as advocates both near to and far from their campus and disciplinary homes.

\section{KEYWORDS}

scholarship of teaching and learning, advocacy, outreach, audiences, policy, SoTLscape, matrix

Advocacy and outreach are birthrights of the scholarship of teaching and learning. From its earliest days, doing SoTL has meant making the work public and taking an unapologetic, indeed proactive, stance toward treating teaching seriously as real intellectual work. By putting the results of their inquiries "out there" to colleagues in their own departments, institutions, and fields, and by joining-or in some cases, initiating - communities of practice around SoTL, scholars and their advocates have been saying to the larger academic community that this is work worth doing.

Yet, to whom, exactly, have scholars of teaching and learning been speaking? We may be doing our share to make teaching community property, as Shulman (1993) proposed, but in what communities? What audiences are we or are we not reaching with our conviction that SoTL is a valuable approach to improving teaching, and that findings from SoTL research should be taken into account in making choices about pedagogy, curriculum, and other factors involved in student success? Are we effective in getting our message across? These questions are at the heart of concern for advocacy and outreach by the International Society for the Scholarship of Teaching and Learning (ISSOTL).

From early days, SoTL scholars have documented the "small significant networks" (Roxå \& Mårtensen, 2009) in which colleagues discuss teaching, and noted how successful models of advocacy and outreach for the work are made available in local gatherings, broadly attended venues like ISSOTL, and publications (see for example, Cambridge, 2004; Hutchings, Huber, \& Ciccone, 2011; and Robinson \& Nelson, 2003). Recent ISSOTL discussions recognize the significance of efforts at this scale 
and seek to situate them in mapping a larger landscape of advocacy and outreach activities in the field. Indeed, once ISSOTL's Advocacy and Outreach Committee had hammered out its mission statement, committee members could see that it had embedded in it a matrix, which included a set of issues (down the side) and a set of audiences (across the top), and thus a way of mapping our collective (and personal) activity to strengthen support for SoTL and give it - where appropriate-a more public address.

Table 1. Matrix of Engagement Possibilities for SoTL Advocacy \& Outreach

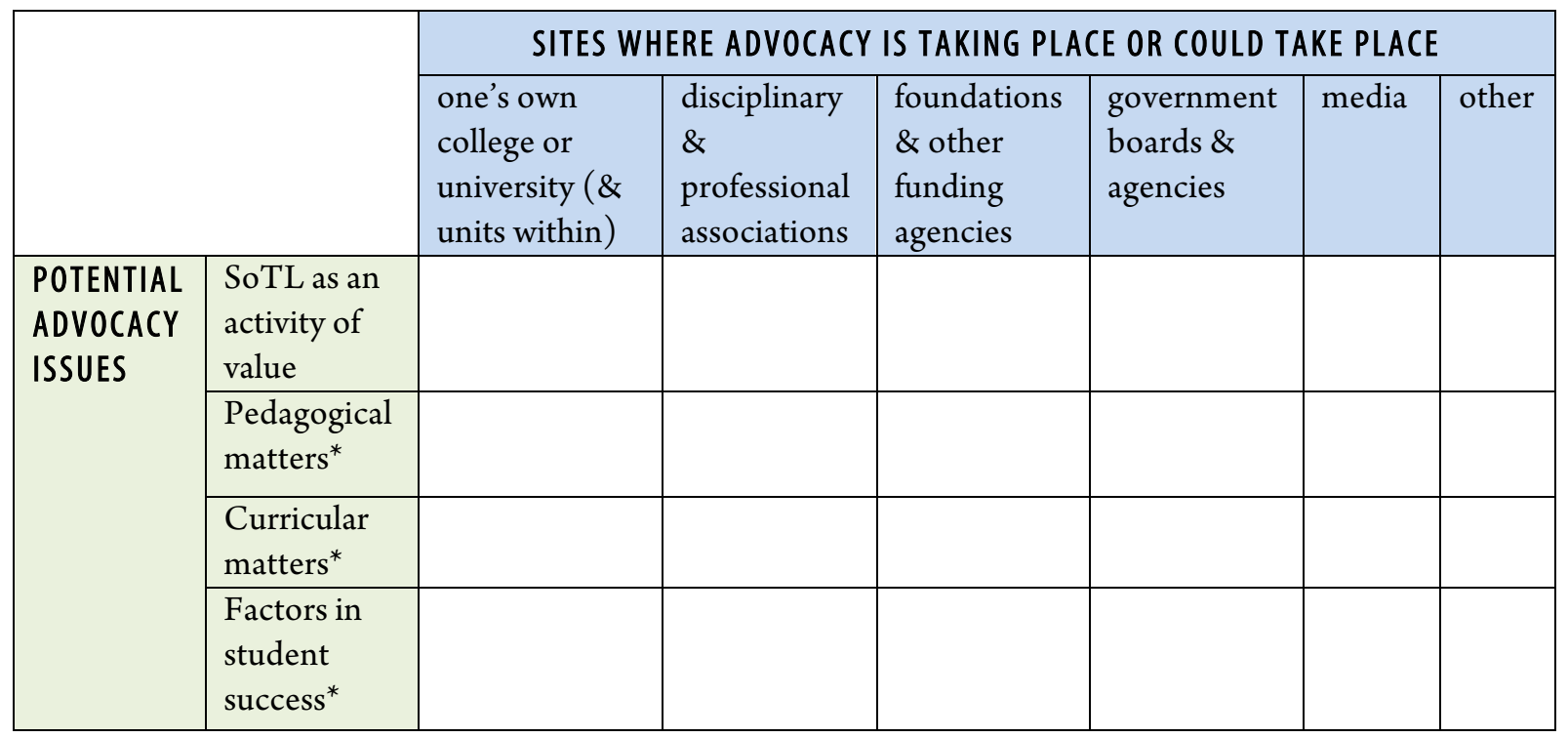

* Typically, this would involve advocacy for particular pedagogies, curricula, and/or factors in student success based on the findings of SoTL research.

A few points about the purposes of this matrix. First, it may be helpful to those trying to conceptualize the areas in which scholars of teaching and learning are already active. Indeed, in addition to making their work public to peers in presentations and publications of various kinds, many practitioners have been involved in advocating for resources and rewards to support SoTL and have brought its findings to bear in important conversations about education. Many scholars of teaching and learning have worked hard and effectively to create an infrastructure and an audience for the work in their colleges and universities and in their disciplinary or professional associations. And many have used their own SoTL research and that of colleagues in arguing for the value of specific learning goals and course and program designs to help achieve them. Published accounts of such advocacy can be found in many of the books and journals of our field.

Second, this matrix might help identify areas where members are perhaps less active. For example, to what extent have scholars of teaching and learning been engaged in sites further away from campus and disciplinary peers and colleagues? Who has been involved in advocacy for the value of SoTL to external funding agencies and to state and national higher education authorities of various kinds? And what about media that reach a wider audience? In the US, that might include media aimed at a more general higher education readership, like the Chronicle of Higher Education, Inside Higher Education, and Change: The Magazine of Higher Learning. Indeed, several key articles about the scholarship of 
teaching and learning by Lee Shulman, Pat Hutchings, Mary Taylor Huber, Dan Bernstein, Mills Kelly, Howard Tinberg, Donna Duffy, Jack Mino-and no doubt others_have been published in Change.

Of course, outreach could also be directed to larger, even non-academic, publics. No doubt some among us have written and published op-eds in local or national news organizations, and contributed to public dialogues and commentary on radio, websites, and social media on appropriate issues and themes - for example, on the teaching of evolution, the design of online learning environments, MOOCs, etc. If so, the larger community of SoTL scholars could benefit from a resource that provided references and/or links that would let them know who, what, when, where, how, and why-perhaps on ISSOTL's new "Accounts of Advocacy and Outreach" webpage.

Finally, beyond mapping current activity and looking for gaps, could the matrix help us organize such a resource in a way that would stimulate imagination about how scholars of teaching and learning could be more effective as advocates? That means encouraging people to write about what they have done in these roles. If it's outreach to a new audience, how did people go about it? If it's advocacy, what specific cause(s) were they advocating for and to whom and how did they make the case? Were they working with their disciplinary association - for example, on a committee to contribute to or critique designs for general education in their college or university or for curricula in their fields for elementary and secondary education? Were they working with others in common cause? Did they have conversations with strategically placed people? Did they get themselves in a position of leadership in the group, like on an important committee? Did they write a report, blog, publish something?

For some academics, advocacy and outreach are terms with different valences. Outreach, at least to our ears, has a largely positive spin. Consider, for example, the local environmental history projects in which SoTL scholar Michael Smith engages his Ithaca College students-a classic kind of communityengaged scholarship that reaches out to local organizations where his students do research and present their work. Michael has presented this pedagogy in various SoTL venues, but also in an essay for a wider readership of higher education faculty in the Indiana University Press volume on Citizenship Across the Curriculum (2010). However, Smith has also published about this work in Taproot, the newsletter of the Coalition for Education in the Outdoors (2014). Titled "Local Environmental History and the Journey to Ecological Citizenship," his article is an illustrated adaptation of his Citizenship Across the Curriculum essay, explaining the value of local environmental history projects to a wider audience of outdoor educators both in and outside the academy.

Advocacy, however, is a term that carries a somewhat different valence than outreach - positive, yes, as it typically involves building alliances and collaborating with a specific community on behalf of a cause you believe in. But, as Catherine Besteman (2013) notes in remarks on "engaged anthropology," a potential for confrontation is more or less built into the term, as "collaboration with one group may imply or require opposition to another" (p.3). Some of the positions that scholars of teaching and learning may advocate for or against may indeed be controversial — and it would be good for people who have been involved in such work to help fellow scholars of teaching and learning chart that territory as well.

Perhaps we can think of the accounts that might fill in the cells in this matrix as features in the "SoTL-scape" (patterned after the term landscape - and other derivatives like soundscape and ethnoscape, to name a few) that can help us think about the experience of engaging in advocacy and outreach in various contexts and that can illuminate where the critical and creative insights that emerge from SoTL inquiries can also move policy, practice, and public debate forward. And, perhaps, too, making pithy accounts of these experiences available on an accessible forum like an ISSOTL webpage can suggest whether there are lessons that we can bring back from these more public engagements that 
would enrich SoTL itself. Perhaps we will even find that engagement in advocacy and outreach can produce knowledge about teaching and learning that can be had in no other way.

\section{ACKNOWLEDGEMENTS}

This paper and the accompanying matrix began their lives as a presentation by the authors at the annual conference of the International Society for the Scholarship of Teaching and Learning in Quebec City, Canada, in October 2014. We wish to acknowledge our colleague, Diana Gregory, who joined us for that presentation and who generously contributed the first Account of Advocacy and Outreach for SoTL on ISSOTL.com. A growing list is available on the ISSOTL Advocacy and Outreach website (http://www.issotl.com/issotl15/node/141). Thanks to those who participated in the lively conversation at that session and to other members of the ISSOTL Advocacy and Outreach Committee. Mary Taylor Huber is senior scholar emerita at the Carnegie Foundation for the Advancement of Teaching and senior scholar with
the Bay View Alliance.

Jennifer Meta Robinson is professor of practice in Anthropology at Indiana University and past president of the International Society for the Scholarship of Teaching and Learning.

\section{REFERENCES}

Besteman, C. (2013). Three reflections on public anthropology. Anthropology Today, 29 (6), 3-6.

Cambridge, B. (2004). Campus progress: Supporting the scholarship of teaching and learning. Washington, D.C.: American Association of Higher Education.

Hutchings, P., Huber, M. T., \& Ciccone, A. (2011). The scholarship of teaching and learning reconsidered: Institutional integration and impact. San Francisco, CA: Jossey-Bass.

ISSOTL Advocacy and Outreach. Retrieved from http://www.issotl.com/issotl15/node/141. Accessed February 16, 2016.

Robinson, J. M., \& Nelson, C. E. (2003). Institutionalizing and diversifying a vision of scholarship of teaching and learning. Journal on Excellence in College Teaching, 14, 95-118.

Roxå, T., \& Mårtensson, K. (2009). Significant conversations and significant networks-Exploring the backstage of the teaching arena. Studies in Higher Education, 34(5), 547-559.

Shulman, L.S. (1993). Teaching as community property: Putting an end to pedagogical solitude. Change 25(6), 67.

Smith, M.B. (2010). Local environmental history and the journey to ecological citizenship. In M B. Smith, R. S. Nowacek, \& J. L. Bernstein (Eds.), Citizenship across the curriculum (pp. 165-184). Bloomington, IN: Indiana University Press.

Smith, M.B. (2014). Local environmental history and the journey to ecological citizenship. Taproot, 23(2), 12-20.

Copyright for the content of articles published in Teaching \& Learning Inquiry resides with the authors, and copyright for the publication layout resides with the journal. These copyright holders have agreed that this article should be available on open access under a Creative Commons Attribution License 4.0 International (https://creativecommons.org/licenses/by/4.0). The only constraint on reproduction and distribution, and the only role for copyright in this domain, should be to give authors control over the integrity of their work and the right to be properly acknowledged and cited, and to cite Teaching \& Learning Inquiry as the original place of publication. Readers are free to share these materials - as long as appropriate credit is given, a link to the license is provided, and any changes are indicated. 